\title{
Potensi Ampas Tebu Sebagai Adsorben Logam Berat Cd, Cu dan $\mathrm{Cr}$
}

\author{
Rusmani Tasanif ${ }^{1}$, Ishak Isa', Wiwin Rewini Kunusa ${ }^{1 *}$ \\ ${ }^{1}$ Program Studi Kimia, Universitas Negeri Gorontalo, Jl. Jend. Sudirman No.6, Kota Gorontalo, 96128
}

\begin{abstract}
ABSTRAK
Penelitian ini bertujuan untuk mengetahui daya serap arang aktif dari ampas tebu dan kondisi optimum arang aktif dalam mengadsorpsi ion logam berat $\mathrm{Cd}, \mathrm{Cu}$ dan $\mathrm{Cr}$ dengan tiga variasi yaitu variasi massa, variasi konsentrasi dan variasi waktu kontak. Limbah ampas tebu memiliki kandungan selulosa yang mampu untuk mengadsorpsi adsorben. Preparasi ampas tebu meliputi pembuatan arang ampas tebu, pembuatan arang aktif secara aktivasi kimia dengan menggunakan larutan $\mathrm{HCl}$, arang aktif yang diperoleh dikarakterisasi meliputi uji kadar air, kadar abu serta analisis gugus fungsi menggunakan Instrument Fourier Infrare (FTIR), dan analisis morfologi arang aktif menggunakan Scanning Electron Microscope (SEM). Aplikasi arang aktif digunakan sebagai adsorben logam berat $\mathrm{Cu}, \mathrm{Cd}$, dan $\mathrm{Cr}$ dengan menggunakan Spektrometri Serapan Atom (SSA). Berdasarkan hasil penelitian menunjukan bahwa kemampuan daya serap adsorpsi arang aktif pada fariasi massa untuk logam $\mathrm{Cd}, \mathrm{Cu}$ dan $\mathrm{Cr}$ diperoleh berat optimum optimum

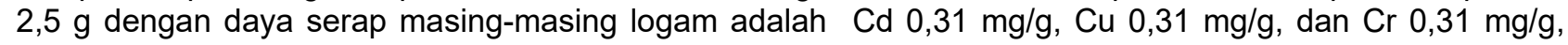
Variasi konsentrasi ion logam $\mathrm{Cd}$ dan $\mathrm{Cu}$ dan $\mathrm{Cr}$ dengan daya serap adsorpsi mencapai kondisi optimum pada daya serap adsorpsi mencapai kondisi optimum pada konsentrasi konsentrasi $2 \mathrm{mg} / \mathrm{L}$ dengan daya serapan masing-masing logam adalah $\mathrm{Cd} 0,19 \mathrm{mg} / \mathrm{g}$, Cu 0,19 mg/g dan $\mathrm{Cr} 0,19 \mathrm{mg} / \mathrm{g}$. Penyerapan optimum logam $\mathrm{Cd}$, $\mathrm{Cu}$ dan $\mathrm{Cr}$ dengan massa adsorben $1 \mathrm{~g}$ adalah mengadsorpsi $\mathrm{Cd}$ 0,7981 mg/g, Cr 0,7995 mg/g sementara untuk logam Cu 0,755 mg/g.
\end{abstract}

Kata kunci: ampas tebu; selulosa; logam berat

\begin{abstract}
The study was aimed at investigating the absorption level of active charcoal of bagasse in optimum condition in adsorbing ion of $\mathrm{Cd}, \mathrm{Cu}$, and $\mathrm{Cr}$. The analyzed parameters were mass, concentration and contact time. The bagasse waste contains cellulose as an active compound with functional groups of Carbon atom for 2, 4 and 6 that were able to adsorb metal. The preparation of bagasse involved the making of active charcoal with the activation in $\mathrm{Hcl}$ solution. The physicochemical characteristics of the produceed active charcoal were characterized, and the functional groups were analyzed using FTIR and morphology analysis using SEM. The application of active charcoal that was used as an adsorbent of $\mathrm{Cd}, \mathrm{Cu}$, and $\mathrm{Cr}$ applied atomic absorption spectrometry (AAS). Mass variation analysis result showed that the optimum weight was $0,5 \mathrm{~g}$ and the adsorption level of Cd was 0,195 mg/g, Cu was 1,47 mg/g and $\mathrm{Cr}$ was 1,59 mg/g. The concentration of variation analysis result showed that the adsorption level achieved the optimum condition at $8 \mathrm{mg} / \mathrm{L}$ concentration, and the adsorption level of Cd was $0,79 \mathrm{mg} / \mathrm{g}$, Cu was $0,76 \mathrm{mg} / \mathrm{g}$ and $\mathrm{Cr}$ was $0,79 \mathrm{mg} / \mathrm{g}$. The optimum time of adsorption of $\mathrm{Cd}, \mathrm{Cu}$ and $\mathrm{Cr}$ by having adsorbent mass for $1 \mathrm{~g}$ adsorbed $\mathrm{Cd}$ for $0,798 \mathrm{mg} / \mathrm{g}$, $\mathrm{Cu}$ for $0,783 \mathrm{mg} / \mathrm{g}$ and $\mathrm{Cr}$ for $0,799 \mathrm{mg} / \mathrm{g}$.
\end{abstract}

Keywords: bagasse; cellulose; heavy metals

Received: 18-08-2019, Accepted: 27-06-2020, Online: 09-07-2020

\section{PENDAHULUAN}

Sejumlah logam berat yang sering ditemui dalam limbah industri yakni cadmium (Cd), zink $(\mathrm{Zn})$, tembaga $(\mathrm{Cu})$, nikel $(\mathrm{Ni})$, timbal $(\mathrm{Pb})$, raksa $(\mathrm{Hg})$, dan kromium $(\mathrm{Cr})$.Jika dilihat dari 
toksitasnya terhadap manusia, sebenarnya ada begitu banyak logam berat yang masuk di dalamnya, namun ada lima logam berat yang menduduki tempat teratas menurut tingkat toksitasnya sehingga Environment protection Agency (EPA) menyertakan dalam bagian "TOP-20" bahan berbahaya dan beracun yakni arsen $(\mathrm{As})$, timbal $(\mathrm{Pb})$, raksa $(\mathrm{Hg})$, cadmium $(\mathrm{Cd})$ dankromium (Cr) (VI) (Sudarmaji, 2006).

Beberapa metode untuk menghilangkan logam berat dari air limbah dilakukan dengan cara fisika dan kimia yang meliputi presipitasi, koagolasi, dan pertukaran ion. Tetapi untuk menghilangkan logam dengan metode-metode tersebut diatas masih sangat mahal terutama bagi negara-negara yang sementara berkembang. Untuk mempertimbangkan biaya pengolahan merupakan salah satu alternatif yang perlu dipertimbangkan untuk memilih teknologi yang digunakan sebagai pengolahan senyawa logam berat (Apriliani, 2010).

Ampas tebu sebagian besar mengandung ligno-cellulose. Memiliki kandungan serat selulosa yang tinggi. Ampas tebu mengandung selulosa sekitar $45 \%$ mengandung air $48-52 \%$, gula rata-rata $3,3 \%$ dan serat rata-rata $47,7 \%$. Selulosa merupakan senyawa yang karakter hidrofilik karena adanya gugus hidroksil pada tiap unit polimernya, permukaan gugus fungsi selulosa alam ataupun turunannya dapat berinteraksi secara fisik atau kimia dengan logam berat (Santosa dkk., 2003).

Adsorben dari ampas tebu juga memiliki beberapa keunggulan yaitu keberadaa yang melimpah sehingga mudah diperoleh, proses preparasi yang mudah, dan biaya relatif murah. Witono (2013) dan Kaur (2008) mengemukakan bahwa ampas tebu juga dapat dimanfaatkan sebagai adsorben logam berat karena memiliki kandungan selulosa yang tinggi serta memiliki kapasitas yang baik dalam mengikat ion logam berat. Oleh karena itu penelitian berinsiatif untuk melakukan penelitian mengenai Potensi Ampas Tebu Sebagai Adsorben Logam Berat Cd (Kadmium), Cu (Tembaga) dan Cr (Krom).

\section{METODE PENELITIAN Alat dan Bahan}

Alat yang digunakan dalam penelitian ini adalah ayakan digital ukuran partikel 80 mesh, neraca analitik, furnace, kertas saring whatman, blender, gelas kimia, erlenmeyer, labu ukur, pipet ukur, pipet volume corong dan oven. Instrumen analisis yakni Spektrofotometri Serapan Atom (SSA), Infra Red FT-IR) dan SEM.

Bahan yang digunakan dalam penelitian ini adalah sampel tebu (diambil dari pabrik gula yang berada di daerah paguyaman) larutan limbah buatan $\mathrm{Cd}\left(\mathrm{NO}_{3}\right)_{2}, \mathrm{~K}_{2} \mathrm{Cr}_{2} \mathrm{O}_{7}, \mathrm{CuSO} \mathrm{O}_{4} .5 \mathrm{H}_{2} \mathrm{O}, \mathrm{HCl}$ $0,1,0,2$ dan 0,3 M Aquades.

\section{Prosedur Penelitian \\ Preparasi Ampas Tebu}

Tahap preparasi sampel terdiri dari pencucian, pengeringan dan penggilingan ampas tebu ditimbang dan di blender hingga menjadi serbuk

\section{Pembuatan Arang Ampas Tebu}

Pada proses pembuatan arang ampas tebu dengan cara sampel diarangkan pada pada suhu $190{ }^{\circ} \mathrm{C}$ dalam furnace selama 45 menit hingga sampel berwarna sampel hitam. Setelah itu diayak dengan ayakan digital dengan ukuran partikel 80 mesh. 


\section{Pembuatan Arang Aktif Dengan Aktivasi Kimia}

Pada tahap pembuatan arang aktif secara aktivasi kimia arang ampas tebu direndam dalam larutan $\mathrm{HCl}$ 0,1, 0,2 dan 0,3 $\mathrm{M}$ selama 24 jam. Kemudian disaring dengan kertas saring dan dicuci dengan aquades hingga $\mathrm{pH}$ netral. Setelah itu sampel dikeringkan pada oven dengan suhu $75^{\circ} \mathrm{C}$ selama 24 jam.

\section{Karakterisasi arang aktif ampas tebu Analisis Kadar Air}

Pada analisis kadar air, serbuk arang aktif ampas tebu sebanyak $1 \mathrm{~g}$ dimasukan kedalam cawan petri yang telah diketahui bobotnya. Selanjutnya dipanaskan dalam oven dengan suhu $100-110{ }^{\circ} \mathrm{C}$ sampai bobotnya konstan selanjutnya didingankan didalam eksikator selama 20 menit dan kemudian ditimbang. Dilakukan hal yang sama berulang-ulang hingga beratnya konstan. Analisis dilakukan triplo (SNI-06-3730-1995). Kadar air dihitung dengan persamaan 1.

$$
\text { Kadar abu }(\%)=\frac{\mathrm{a}-\mathrm{b}}{\mathrm{c}} \times 100 \%
$$

\section{Dengan:}

$\mathrm{a}=$ bobot sampel dan cawan petri sebelum dikeringkan (gram)

$\mathrm{b}=$ bobot sampel dan cawan petri sesudah dikeringkan (gram)

$\mathrm{c}=$ bobot sampel sebelum dikeringkan (gram)

\section{Analisis Kadar Abu}

Pada analisis kadar air, serbuk arang aktif ampas tebu sebanyak $1 \mathrm{~g}$ dimasukan kedalam cawan petri yang telah diketahui bobotnya sebelum pengabuan. Selanjutnya dipanaskan dalam furnace dengan suhu $500{ }^{\circ} \mathrm{C}$ selama 3 jam sampai bobotnya konstan selanjutnya didingankan didalam eksikator selama 20 menit dan kemudian ditimbang. Dilakukan hal yang sama berulangulang hingga beratnya konstan. Analisis dilakukan triplo (SNI-06-3730-1995). Kadar abu dihitung dengan persamaan 2 .

$$
\text { Kadar abu }(\%)=\frac{\mathrm{a}-\mathrm{b}}{\mathrm{c}} \times 100 \%
$$

Dengan:

$\mathrm{a}=$ bobot sampel dan cawan petri sebelum dikeringkan (gram)

$\mathrm{b}=$ bobot sampel dan cawan petri sesudah dikeringkan (gram)

$c=$ bobot sampel sebelum dikeringkan (gram)

\section{Analisis FTIR}

Proses analisis senyawa kimia dilakukan dengan menggunakan Fourier Transfrom infra red (FTIR). Analisis $\alpha$-selulosa menggunakan FTIR dilakukan dengan cara 0,2 g arang aktif dicampur dengan $2 \mathrm{mg} \mathrm{KBr}$ dan dibentuk menjadi pellet. Pellet dari sampel kemudian dimasukan keinstrumen FTIR dengan $\lambda$ 4000-400.

\section{Analisis SEM}

Analisis SEM pada a-selulosa dilakukan dengan cara serbuk selulosa dibekukan diatas aluminium sampai kering. Kemudian sampel dipercikan dengan emas selama 30 menit menggunakan palaron. Hasil analisis ditampilkan dalam stereoscan. 
Aplikasi arang aktif ampas tebu sebagai adsorben logam berat $\mathrm{Cd}$, $\mathrm{Cu}$ dan $\mathrm{Cr}$.

Pembuatan larutan induk $\mathrm{Cd}\left(\mathrm{NO}_{3}\right)_{2}, \mathrm{CuSO}_{4} \cdot \mathrm{H}_{2} \mathrm{O}$ dan $\mathrm{K}_{2} \mathrm{Cr}_{2} \mathrm{O}_{7}$

Larutan induk $\mathrm{Cd}\left(\mathrm{NO}_{3}\right)_{2}, \quad \mathrm{CuSO}_{4} \cdot \mathrm{H}_{2} \mathrm{O}$ dan $\mathrm{K}_{2} \mathrm{Cr}_{2} \mathrm{O}_{7}$ dibuat masing-masing dengan konsentrasi $1000 \mathrm{ppm}$ dengan volume $1000 \mathrm{~mL}$ Pembuatan larutan dengan cara melarutkan $\mathrm{Cd}\left(\mathrm{NO}_{3}\right)_{2}$, sebanyak 2,1074 $\mathrm{g}$, CuSO ${ }_{4} \cdot \mathrm{H}_{2} \mathrm{O}$ sebanyak $3,9062 \mathrm{~g}$ dan $\mathrm{K}_{2} \mathrm{Cr}_{2} \mathrm{O}_{7}$ sebanyak $2,8275 \mathrm{~g}$ masing-masing dilarutkan kedalam $1000 \mathrm{~mL}$ aquades.

\section{Pembuatan larutan kerja}

Masing-masing larutan induk $\mathrm{Cr}, \mathrm{Cd}, \mathrm{Cu} 1000 \mathrm{mg} / \mathrm{L}$ dipipet $10 \mathrm{~mL}$ dan dimasukkan ke dalam labu ukur $100 \mathrm{~mL}$, kemudian ditambahkan aquades hingga tanda tera dan dihomogenkan.

Tahap pelaksanaan analisis mekanisme adsorpsi

Pengujian daya adsorpsi adsorben berdasarkan variasi konsentrasi

Diambil arang aktif masing-masing sebanyak $1 \mathrm{~g}$, campurkan dengan $100 \mathrm{~mL}$ larutan $\mathrm{Cd}\left(\mathrm{NO}_{3}\right)_{2}, \mathrm{~K}_{2} \mathrm{Cr}_{2} \mathrm{O}_{7}$ dan $\mathrm{CuSO}_{4} .5 \mathrm{H}_{2} \mathrm{O}$ 2, 4, 6, 8 ppm ke dalam gelas kimia. Kemudian didiamkan selama 60 menit setelah itu larutan disaring menggunakan kertas saring. Filtrat dianalisis mengguanakan AAS.

\section{Pengujian daya adsorpsi adsorben berdasarkan variasi massa}

Diambil arang aktif dengan variasi massa 0,5, 1, 1,5, 2, dan 2,5 g diadsorpsi masingmasing kedalam $100 \mathrm{~mL}$ larutan $\mathrm{CdSO}_{4} .8 \mathrm{H}_{2} \mathrm{O}, \mathrm{K}_{2} \mathrm{Cr}_{2} \mathrm{O}_{7}$ dan $\mathrm{CuSO}_{4} .5 \mathrm{H}_{2} \mathrm{O} 8 \mathrm{ppm}$. Campuran tersebut diaduk dengan magnetic stirrer pada kecepatan selama 30 menit pada suhu $30^{\circ} \mathrm{C}$. Setelah pengadukan selesai, campuran didiamkan dan dibiarkan selama 60 menit sehingga dapat mengendap dengan sempurna. Setelah itu larutan disaring menggunakan kertas saring. Filtrat dianalisis mengguanakan AAS

\section{Pengujian daya adsorpsi adsorben berdasarkan variasi waktu kontak}

Diambil arang aktif sebanyak $1 \mathrm{~g}$ diadsorpsi dalam $100 \mathrm{ml}$ larutan $\mathrm{CdNO}_{3}, \mathrm{~K}_{2} \mathrm{Cr}_{2} \mathrm{O}_{7}$ dan $\mathrm{CuSO}_{4} .5 \mathrm{H}_{2} \mathrm{O} 8 \mathrm{ppm}$ kedalam gelas kimia. Campuran tersebut diaduk dengan magnetic stirrer selama $15,30,45,60$, dan 75 menit pada suhu $30^{\circ} \mathrm{C}$. Setelah pengadukan selesai, campuran didiamkan dan dibiarkan selama 60 menit sehingga dapat mengendap dengan sempurna. setelah itu larutan disaring menggunakan kertas saring. Filtrat dianalisis mengguanakan AAS.

\section{Penentuan Jumlah Cd(II), Cu(II) dan Cr (II) yang teradsorpsi dalam arang aktif ampas tebu}

Jumlah $\mathrm{Cd}(\mathrm{II}), \mathrm{Cu}(\mathrm{II})$ dan $\mathrm{Cr}(\mathrm{II})$ yang teradsorpsi oleh arang aktif ampas tebu dapat dihitung menggunakan rumus pada persamaan 3 .

$$
\% \text { adsorpsi }=\frac{(C o-C s)}{C o} \times 100 \%
$$

dimana:

Co = Konsentrasi Cd (II), $\mathrm{Cu}$ (II) dan $\mathrm{Cr}$ (II) sebelum teradsorpsi (mg/L)

Cs = Konsentrasi Cd (II) dan $\mathrm{Cu}$ (II) dan $\mathrm{Cr}$ (II) sesudah teradsorpsi (mg/L).

\section{Perhitungan kapasitas adsorpsi Cd (II), Cu (II) dan Cr (II)}

Kapasitas adsorpsi arang aktif ampas tebu terhadap $\mathrm{Cd}(\mathrm{II}), \mathrm{Cu}(\mathrm{II})$ dan $\mathrm{Cr}(\mathrm{II})$ dapat dihitung dengan menggunakan persamaan 4 . 


$$
Q o=\frac{(C o-C s) \cdot V}{M}
$$

dimana:

$\mathrm{Q}_{0} \quad=$ Kapasitas adsorbsi $(\mathrm{mg} / \mathrm{g})$

Co $\quad=$ konsentrasi logam sebelum teradsorpsi $(\mathrm{mg} / \mathrm{L})$

Cs = konsentrasi logam sesudah teradsorpsi (mg/L)

$M \quad=$ Massa adsorben yang digunakan $(\mathrm{g})$

$\mathrm{V} \quad=$ Volume larutan logam $(\mathrm{L})$

\section{HASIL DAN PEMBAHASAN}

\section{Preparasi Sampel Ampas Tebu}

Penelitian ini digunakan sekitar $1000 \mathrm{~g}$ ampas tebu yang diambil dari PT.PG tolanghula tepatnya di desa Paguyaman Kab. Gorontalo. Perlakuan awal terhadap ampas tebu berupa pencucian, pengeringan, penggilingan, pengarangan dan pengayakan hasil preparasi ampas tebu ukuran 80 mesh diperoleh sebanyak $300 \mathrm{~g}$

\section{Proses Aktivasi Kimia}

Pada aktivasi kimia, karbon diaktivasi melalui perendaman reagen bahan kimia sebelum dipanaskan pada suhu tinggi bahan pengaktif akan masuk diantara sela-sela lapisan heksagonal dan selanjutnya membuka permukaan yang tertutup.

Proses aktivasi kimia pada penelitian ini dilakukan dengan cara merendam (Maserasi) arang ampas tebu dalam larutan $\mathrm{HCl}$ dengan variasi konsentrasi $\mathrm{HCl} 0,1 \mathrm{M}$ sebanyak $25 \mathrm{~g}, \mathrm{HCl}$ $0,2 \mathrm{M} 50 \mathrm{~g}$ dan $\mathrm{HCl} 0,3 \mathrm{M}$ sebanyak $25 \mathrm{~g}$ arang ampas tebu selama 24 jam. Tujuan aktivasi untuk memperbesar diameter pori dan menambah serta mengembangkan volume pori adsorben selama penyerapan. Hasil pada aktivasi diperoleh bahwa konsentrasi $\mathrm{HCl} 0,1 \mathrm{M}$ sebanyak $24,7 \mathrm{~g}, \mathrm{HCl} 0,2$ M sebanyak 48,5 g, dan $\mathrm{HCl}$ 0,3M sebanyak 24,4 g.

\section{Karakterisasi arang aktif ampas tebu \\ Penetapan kadar air}

Analisis kadar air dari adsorben ampas tebu penting dilakukan untuk mengetahui seberapa besar kadar air yang ada pada adsorben tersebut Proses uji kadar air dilakukan secara triplo sesuai dengan SNI-06-3730-1995 dengan 3x pengulangan uji kadar air menunjukan nilai rata-rata kadar air sebesar $3.48 \%$.

Kandungan air maksimum yang diperbolehkan adalah sebesar 10\% Rendahnya kandungan air menunjukan bahwa kandungan air bebas dan air yang terdapat dalam bahan telah menguap selama proses karbonisasi.

Kandungan air dalam suatu senyawa dapat dipengaruhi kemampuan adsorpsi suatu adsorben. Hal ini karena tinggi rendahnya kadar air menunjukan banyak sedikitnya air yang menutupi pori-pori adsorben. Semakin rendah kadar air maka semakin banyak tempat dalam pori yang dapat ditempati oleh adsorbat sehingga adsorpsi berlangsung secara optimal (Rahayu, dkk. 2014).

\section{Penetapan Kadar Abu.}

Penentuan kandungan abu dilakukan untuk mengetahui sisa mineral yang tertinggal pada saat pembakaran berlangsung dimana sebagian dari mineral ini telah hilang pada saat karbonisasi dan sebagian lagi masih tertinggal dalam arang ampas tebu. Proses uji kadar abu dilakukan 
secara triplo sesuai dengan SNI-06-3730-1995 dengan 3X pengulangan. Data hasil uji kadar abu rata-rata sampel diperoleh sebesar $3.52 \%$ nilai kandungan abu maksimum yang diperbolehkan adalah $15 \%$.

\section{Analisis FTIR}

Analisis gugus fungsional dilakukan menggunakan instrumen FTIR. Pada pengujian ini digunakan selulosa standar sebagai pembanding yaitu Avicel 102. Kemurnian selulosa akan menunjukan serapan utama pada bilangan gelombang 3344, 2884, 1426, 1316, dan $1024 \mathrm{~cm}^{-1}$ mengindikasikan adanya gugus $\mathrm{OH}$, ikatan hidrogen, $\mathrm{C}-\mathrm{H}$ alkana, ikatan $\mathrm{C}-\mathrm{O}$ eter dan alkohol (Yanuar et al. 2003).

Dalam penelitian ini, yakni pada proses aktivasi arang aktif dilakukan dalam suasana asam menggunakan HCL 0,1, 0,2 dan 0,3 M. Hasil spektrum FTIR seperti ditunjukkan pada gambar 1 .

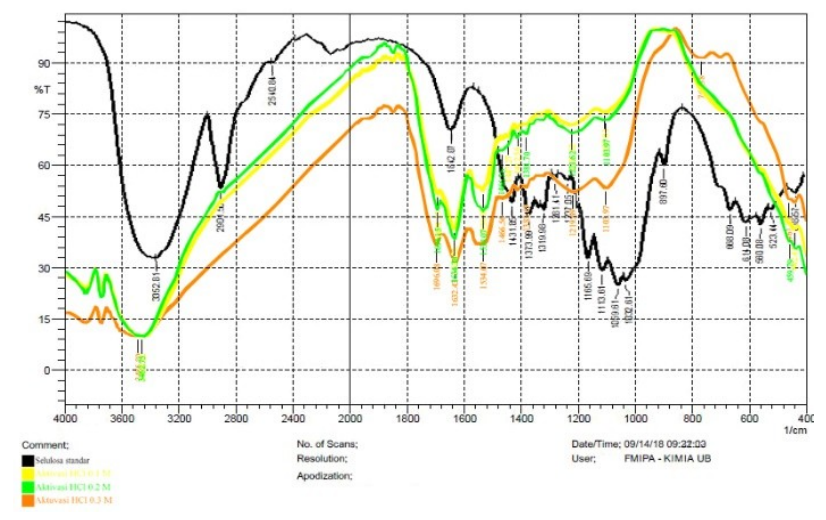

Gambar 1. Hasil Spektra FTIR

Berdasarkan analisis data FTIR pada gambar 1 menunjukkan puncak serapan yang menandakan adanya gugus fungsi pada arang aktif ampas tebu. Selanjutnya interpretasi data

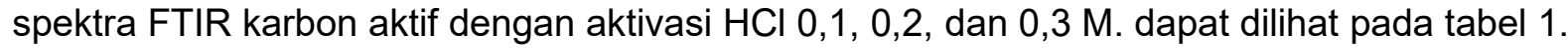

Tabel 1. Interpretasi data spektra FTIR karbon aktif dengan aktivasi $\mathrm{HCl} 0,1,0,2$ dan $0,3 \mathrm{M}$

\begin{tabular}{|c|c|c|c|}
\hline Aktivasi & $\begin{array}{c}\text { Bilangan } \\
\text { gelombang }\end{array}$ & $\begin{array}{l}\text { Ikatan( jenis } \\
\text { vibrasi) }\end{array}$ & $\begin{array}{c}\text { Intensitas } \\
\text { pita }\end{array}$ \\
\hline $0.1 \mathrm{M} \mathrm{HCl}$ & 3460.15 & $\mathrm{O}-\mathrm{H}$ (stretching) & Tajam \\
\hline $0.2 \mathrm{M} \mathrm{HCl}$ & 3462.75 & $\mathrm{O}-\mathrm{H}$ (stretching) & Tajam \\
\hline $0.3 \mathrm{M} \mathrm{HCl}$ & 3485.89 & $\mathrm{OH}$ (stretching) & Melebar \\
\hline $0.1 \mathrm{M} \mathrm{HCl}$ & $\begin{array}{l}1694.15- \\
1634.36\end{array}$ & $\begin{array}{c}\mathrm{C}=\mathrm{O} \text { karbonil } \\
\text { (stretching) }\end{array}$ & Tajam \\
\hline $0.2 \mathrm{M} \mathrm{HCl}$ & $\begin{array}{l}1694.15- \\
1634.36\end{array}$ & $\begin{array}{c}\mathrm{C}=\mathrm{O} \\
\text { karbonil(stretching }\end{array}$ & $\begin{array}{l}\text { Sangat } \\
\text { tajam }\end{array}$ \\
\hline $0.3 \mathrm{M} \mathrm{HCl}$ & $\begin{array}{l}1696.08- \\
1632.43\end{array}$ & $\begin{array}{l}\mathrm{C}=\mathrm{O} \text { karbonil } \\
\text { (stretching) }\end{array}$ & Melebar \\
\hline $0.1 \mathrm{M} \mathrm{HCl}$ & 1534.07 & $\mathrm{C}-\mathrm{H}$ bending & Melebar \\
\hline $0.2 \mathrm{M} \mathrm{HCl}$ & 1534.07 & $\mathrm{C}-\mathrm{H}$ bending & Tajam \\
\hline $0.3 \mathrm{M} \mathrm{HCl}$ & 1534.07 & $\mathrm{C}-\mathrm{H}$ bending & Melebar \\
\hline
\end{tabular}


Analisis FTIR menunjukkan bahwa karbon aktif yang diaktivasi dengan konsentrasi $\mathrm{HCl} 0,1$ $\mathrm{M}$ dan 0,2 $\mathrm{M}$ memberikan serapan yang tajam yang ditunjukkan oleh gugus $-\mathrm{OH}$ yang tajam dan melebar pada bilangan gelombang $3462.75 \mathrm{~cm}^{-1}$ dibandingkan dengan serapan pada aktivasi $0,3 \mathrm{M}$ $\mathrm{HCl}$. Pada bilangan gelombang 1634.36 - 1632,43 untuk aktivasi $\mathrm{HCl}$ 0,2 M memberikan serapan $\mathrm{C}-\mathrm{O}$ karbonil yang sangat tajam. Demikian pula untuk gugus fungsi $\mathrm{C}-\mathrm{H}$ alkil pada masing-masing konsentrasi menujukkan serapan pada bilangan gelombang yang sama yakni 1534,07.

Akan tetapi untuk aktivasi $0,2 \mathrm{M} \mathrm{HCl}$ memberikan serapan dengan peak yang lebih tajam,

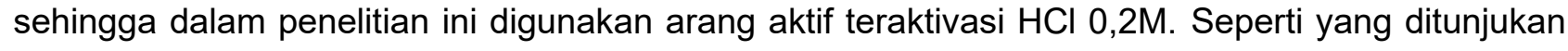
pada gambar 2 .

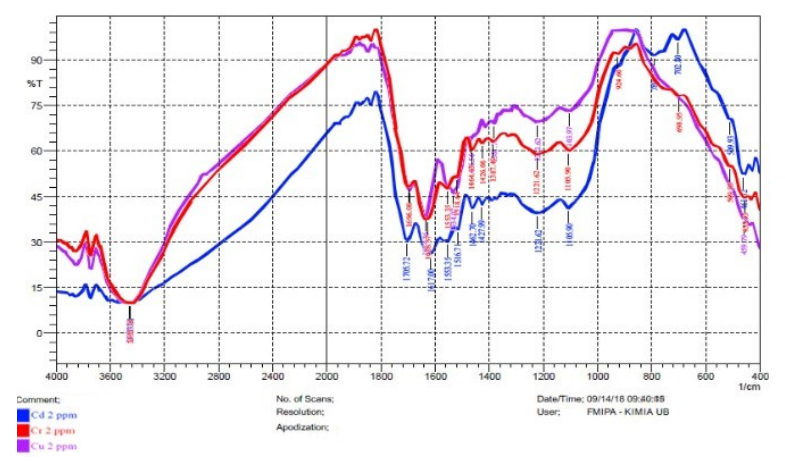

Gambar 2. Hasil Analisis FTIR arang aktif dengan logam.

Berdasarkan hasil analisis FTIR dalam proses adsorpsi karbon aktif terhadap ion logam $\mathrm{Cu}^{2+}, \mathrm{Cr}^{2+}$, dan $\mathrm{Cd}^{2+}$ pada Gambar 2 dan Tabel 2 menujukkan adanya pita serapan yang tajam dan lebar pada bilangan gelombang $3453,11 \mathrm{~cm}^{-1}$ untuk logam $\mathrm{Cd}$, dan pita yang lebar pada bilangan gelombang 3522,54 $\mathrm{cm}^{-1}$ untuk logam Cu dan 3451,18 $\mathrm{cm}^{-1}$ untuk logam $\mathrm{Cr}$.

Kemudian pada pembacaan serbuk ampas tebu selanjutnya mengalami pergeseran peak yang tajam dan lebar pada puncak serapan menjadi $1617.00 \mathrm{~cm}^{-1}$ untuk $\mathrm{Cd}, 1628.57 \mathrm{~cm}^{-1}$ untuk Cu dan $1620.86 \mathrm{~cm}^{-1}$ untuk $\mathrm{Cr}$ yang menunjukan bahwa adanya gugus C-O karbonil Selanjutnya interpretasi data spektra FTIR dalam proses adsorpsi karbon aktif terhadap ion logam $\mathrm{Cu}^{2+}, \mathrm{Cr}^{2+}$, dan $\mathrm{Cd}^{2+}$.

Mekanisme adsorpsi yang terjadi pada bilangan gelombang antara $3453,11 \mathrm{~cm}^{-1}, 3522,54$ $\mathrm{cm}^{-1}$ dan $3451,18 \mathrm{~cm}^{-1}$ yakni pada gugus fungsi $-\mathrm{OH}$ hidroksil dari karbon aktif yang terikat pada permukaan struktur arang aktif ampas tebu. Berikut adalah mekanisme pertukaran ion seperti yang di tunjukan pada gambar 3 .

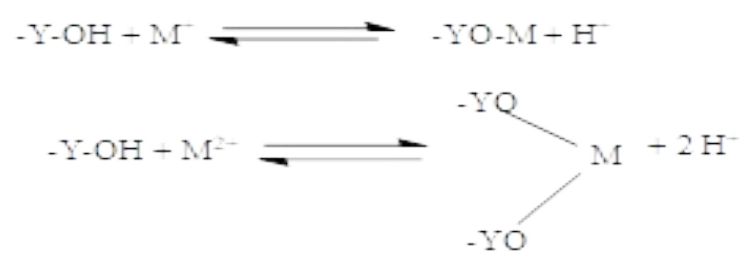

Gambar 3. Pertukaran ion dengan adsorbat

$\mathrm{M}$ dan $\mathrm{M}^{+}$adalah ion logam, $-\mathrm{OH}$ adalah gugus hidroksil dan $\mathrm{Y}$ adalah matriks tempat gugus $-\mathrm{OH}$ terikat. Interaksi antara gugus $-\mathrm{OH}$ dengan ion logam juga memungkinkan terjadinya mekanisme pertukaran ion. Perihal tersebut menunjukan bahwa selulosa sebagai Chelating agent. 
Tabel 2. Hasil Analsis data FTIR dalam adsorpsi Arang Ampas Tebu dengan Logam

\begin{tabular}{c|lll}
\hline Aktivasi & \multicolumn{1}{|c}{$\begin{array}{c}\text { Bilangan } \\
\text { gelombang }\end{array}$} & \multicolumn{1}{c}{ Gugus fungsi } & \multicolumn{1}{c}{ Keterangan } \\
\hline $\mathrm{Cu}$ & 3522.54 & $\mathrm{O}-\mathrm{H}$ (stretching) & Melebar \\
$\mathrm{Cd}$ & 3453.11 & $\mathrm{O}-\mathrm{H}$ (stretching) & Lebar \\
$\mathrm{Cr}$ & 3451.18 & $\mathrm{OH}$ (stretching) & Tajam dan melebar \\
$\mathrm{Cu}$ & $1701.66-1620.86$ & $\mathrm{C}=\mathrm{O}$ karbonil (stretching) & Tajam dan lebar \\
$\mathrm{Cd}$ & $1705.72-1617.00$ & $\mathrm{C}=\mathrm{O}$ karbonil(stretching) & Tajam \\
$\mathrm{Cr}$ & $1696.08-1628.57$ & $\mathrm{C}=\mathrm{O}$ karbonil (stretching) & Sangat tajam \\
$\mathrm{Cu}$ & 1553.35 & $\mathrm{C}-\mathrm{H}$ bending & Tajam \\
$\mathrm{Cd}$ & 1553.35 & $\mathrm{C}-\mathrm{H}$ bending & Sedikit tajam \\
$\mathrm{Cr}$ & 1553.35 & $\mathrm{C}-\mathrm{H}$ bending & Sedikit tajam \\
\hline
\end{tabular}

\section{Analisis SEM}

Pada penelitian ini dilakukan aktivasi kimia dengan menggunakan larutan $\mathrm{HCl}$ yang mempunyai sifat higroskopis hingga mampu menyerap kandungan air pada arang ampas tebu menggunaka SEM. Hasil analisis SEM (a) arang ampas tebu sebelum aktivasi (b) arang aktif telah diaktivasi dengan $\mathrm{HCl} \mathrm{0,2} \mathrm{M} \mathrm{dan} \mathrm{(c)} \mathrm{selulosa} \mathrm{standar.} \mathrm{Hal} \mathrm{ini} \mathrm{disajikan} \mathrm{pada} \mathrm{gambar} 4$.
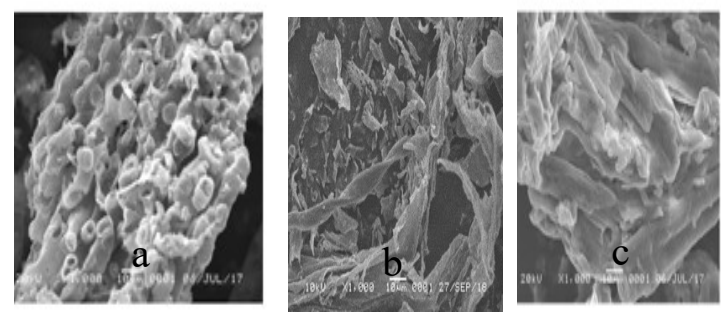

Gambar 4. Hasil analisis SEM

Berdasarkan hasil analisis SEM karbon aktif dari ampas tebu sebelum diaktivasi dengan larutan $\mathrm{HCl}$ dengan perbesaran 1000 kali dengan memiliki ukuran partikel $10 \mu \mathrm{m}$ pada gambar 3 (a) morfologi permukaan arang ampas tebu setelah karbonisasi terlihat distribusi pori-pori namun pori-pori tersebut terlihat masih banyak pengotor sehingga pori-pori sulit untuk dilihat, 3 . (b) Morfologi permukaan pada arang ampas tebu proses aktivasi dengan $\mathrm{HCl} 0,2 \mathrm{M}$ lebih terlihat adanya pori yang terbentuk dalam arang ampas tebu, hal ini dikarenakan aktivasi dengan $\mathrm{HCl}$ dapat melarutkan pengotor sehingga pori-pori terbuka dan proses penjerapan adsorbat menjadi lebih maksimal (Nurhasni 2014).

\section{Aplikasi Arang Aktif sebagai Adsorben ion logam berat $\mathrm{Cd}, \mathrm{Cu}$ dan $\mathrm{Cr}$ Penentuan Massa optimum Arang Aktif Ampas Tebu}

Analisis kemampuan adsorpsi arang aktif terhadap logam $\mathrm{Cd}, \mathrm{Cu}$ dan $\mathrm{Cr}$ digunakan alat Spektrometri Serapan Atom (SSA). Hasil yang didapat sebagaimana disajikan dalam gambar 5 . 
bahwa diperoleh berat optimum $0,5 \mathrm{~g}$ dengan daya serap masing-masing logam adalah $\mathrm{Cd}$ 1,95 $\mathrm{mg} / \mathrm{g}$, Cu $1,47 \mathrm{mg} / \mathrm{g}$, dan $\mathrm{Cr} 1,59 \mathrm{mg} / \mathrm{g}$.

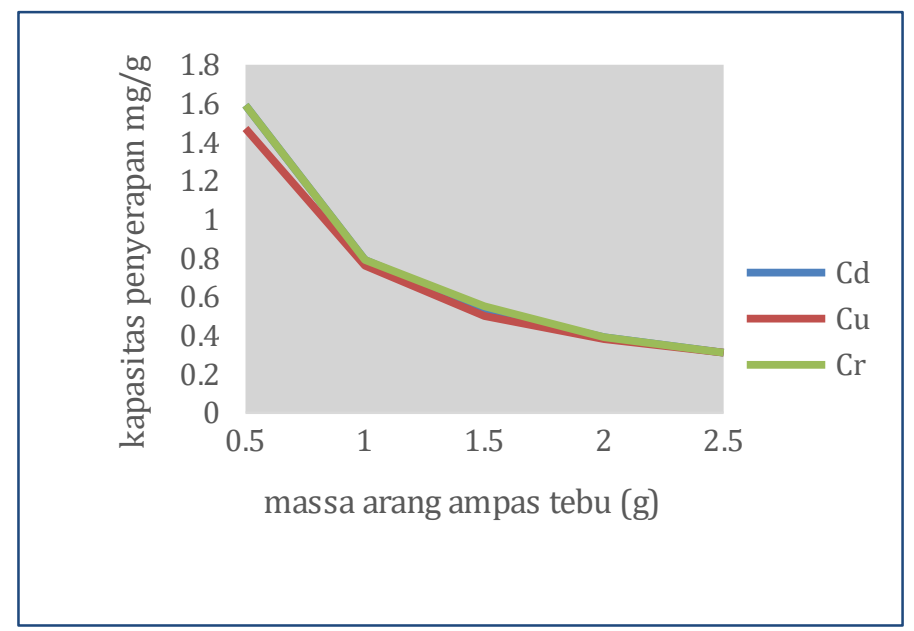

Gambar 5. Kurva Pengaruh Massa Arang Aktif Ampas Tebu Terhadap Daya Serap Ion Logam Cd, Cu dan Cr.

\section{Penentuan Konsentrasi optimum lon Logam}

Kemampuan penyerapan suatu adsorben dipengaruhi oleh konsentrasi dari larutan ion logam tersebut Pada gambar 6. menunjukan pengaruh konsentrasi ion logam terhadap daya serap arang ampas tebu. Kondisi optimum penyerapan dicapai pada konsentrasi $8 \mathrm{mg} / \mathrm{L}$ dengan daya

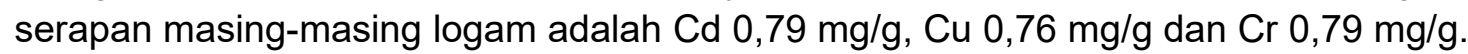

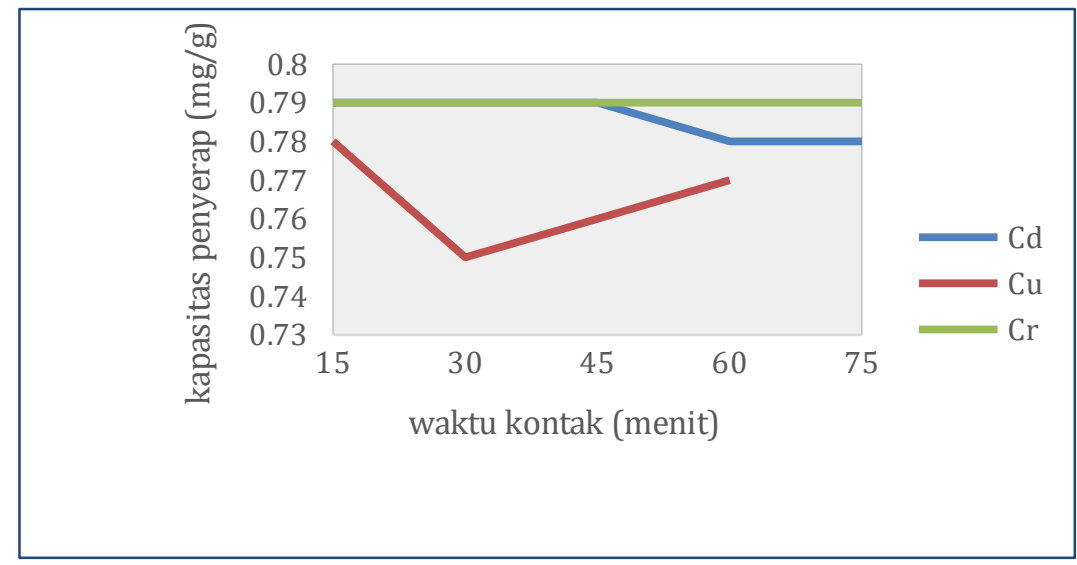

Gambar 6. Kurva Konsentrasi lon Logam Cd, Cu dan Cr Terhadap Daya Serap Arang Aktif Ampas Tebu.

\section{Penentuan Waktu Kontak}

Pada gambar 7. menunjukan bahwa karbon aktif dari ampas tebu memiliki waktu kontak 15 menit untuk logam Cu dan $\mathrm{Cr}$ sementara untuk logam Cd 75 menit. Hal ini menunjukan bahwa $1 \mathrm{~g}$ karbon aktif ampas tebu mampu mengadsorpsi Cu 0,783 mg/g, Cr 0,799 mg/g sementara untuk logam Cd 0,798 mg/g.

Berdasarkan kemampuan mengadsorpsi arang aktif terhadap logam berat $\mathrm{Cd}^{2+}, \mathrm{Cu}^{2+}$ dan $\mathrm{Cr}^{2+}$ ion logam $\mathrm{Cd}^{2+}$ lebih tinggi dari pada ion logam berat $\mathrm{Cu}^{2+}$ dan $\mathrm{Cr}^{2+}$. 


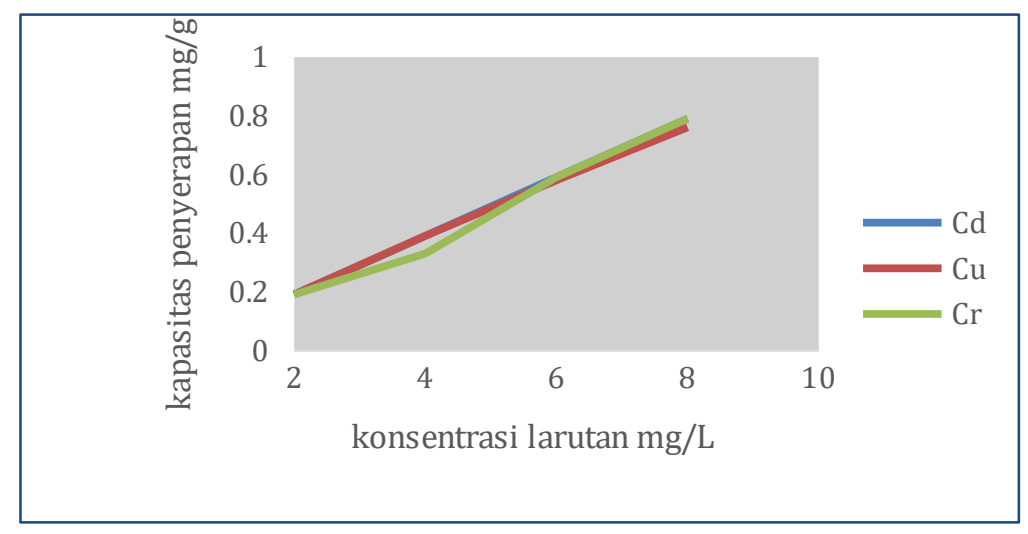

Gambar 7. Kurva Pengaruh Waktu Kontak Ion Logam Cd, Cu dan Cr Terhadap Daya Serap Arang Aktif Ampas Tebu.

Hal ini dikarenakan ion logam $\mathrm{Cd}^{2+}$ memiliki molekul relativ yang lebih tinggi jika dibandingkan dengan ion logam $\mathrm{Cu}^{2+}$ dan $\mathrm{Cr}^{2+}$ dengan nilai $\mathrm{Mr}$ adalah 236,4 g/mol sedangkan $\mathrm{Cu}^{2+}$ dan $\mathrm{Cr}^{2+}$ masing-masing adalah $187,5 \mathrm{~g} / \mathrm{mol}$ dan $104,11 \mathrm{~g} / \mathrm{mol}$ sehingga ion logam $\mathrm{Cd}^{2+}$ lebih cepat jatuh sampai kepermukaan adsorben dari pada ion logam $\mathrm{Cu}^{2+}$ dan $\mathrm{Cr}^{2+}$.

Selain itu logam berat kadmium $(\mathrm{Cd})$ dari $\mathrm{Cd}\left(\mathrm{NO}_{3}\right)_{2}$ memiliki nomor atom lebih besar dari pada logam $\mathrm{Cu}$ dari $\mathrm{CuSO}_{4} .5 \mathrm{H}_{2} \mathrm{O}$ dan $\mathrm{Cr}$ dari $\mathrm{K}_{2} \mathrm{Cr}_{2} \mathrm{O}_{7}$ yang menunjukan jumlah proton yang dimiliki oleh $\mathrm{Cd}^{2+}$ lebih besar dari pada $\mathrm{Cu}^{2+}$ dan $\mathrm{Cr}^{2+}$ ini mengakibatkan daya tarik inti dan muatan inti efektif yang dimiliki $\mathrm{Cd}^{2+}$ lebih besar sehingga lebih mempermudah ion logam $\mathrm{Cd}^{2+}$ dalam selulosa yang terkandung dalam arang aktif yang bersifat nonpolar dan membentuk gaya tarik elektrostatik.

\section{SIMPULAN}

Kemampuan daya serap adsorpsi arang aktif pada fariasi massa untuk logam $\mathrm{Cd}$, Cu dan $\mathrm{Cr}$ diperoleh massa optimum $0,5 \mathrm{~g}$ dengan daya serap masing-masing logam adalah $\mathrm{Cd}$ 1,95 mg/ $\mathrm{g}$, Cu $1,47 \mathrm{mg} / \mathrm{g}$, dan $\mathrm{Cr} 1,59 \mathrm{mg} / \mathrm{g}$. Daya serap adsorpsi mencapai kondisi optimum pada konsentrasi $8 \mathrm{mg} / \mathrm{L}$ dengan daya serapan masing-masing logam adalah $\mathrm{Cd} \mathrm{0,79} \mathrm{mg/g,} \mathrm{Cu} \mathrm{0,76}$ $\mathrm{mg} / \mathrm{g}$ dan $\mathrm{Cr}$ 0,79 mg/g. Penyerapan optimum logam $\mathrm{Cd}$, Cu dan $\mathrm{Cr}$ dengan massa adsorben $1 \mathrm{~g}$ karbon aktif ampas tebu mampu mengadsorpsi $\mathrm{Cd} 0,798 \mathrm{mg} / \mathrm{g}, \mathrm{Cu} 0,783 \mathrm{mg} / \mathrm{g}$ sementara untuk logam $\mathrm{Cr}$ 0,799 mg/g dengan waktu masing-masing adalah $\mathrm{Cd} 75$ menit, $\mathrm{Cu}$ dan $\mathrm{Cr} 15$ menit. Disarankan untuk melakukan penelitian lebih lanjut mengenai adsorben logam berat menggunakan ampas tebu dan pemanfaatan arang dari ampas tebu sebagai bahan absorben dengan metode yang berbeda.

\section{DAFTAR PUSTAKA}

Apriliani, A. 2010. Pemanfaatan Arang Ampas Tebu sebagai Adsorben lon Logam Cd, $\mathrm{Cr}$, $\mathrm{Cu}$ dan $\mathrm{Pb}$ dalam Air Limbah. Skripsi. UIN Syarif Hidayatullah, Jakarta.

Aslam, Mohd, Sumbul, Rais, Masood, Alam, and Arulazhagan Pugazhedi. 2013. Adsorption by Hg(II) From Aqueous Using Adulsa (Justicaadhotoda) Leaves Powder: Kinetic and Equilibrium Studie. Journal of Chemistry

Atkins, Peter dan Julio de Paula. 2006. Physical chemistry, Eight Edition. Oxford Unversity Press. New York. 
Husain, 2007, Analisis Serat Bagas, (Http://www. free. vlasm. Org./ diakses pada tanggal 11 oktober 2017

Kaur S, Walia T.P.S and Mahajan R.K. 2008 Comparative Studies of Zink, Cadmium, Lead and Copper on Economically Viable Adsorbents. Journal Environ EngSci 7: 1-8.

Nurhasni, Hendrawati, Nubzah Saniyyah., Sekam Padi untuk Menyerap Ion Logam Tembaga dan Timbal dalam Air Limbah, ISSN: 1978-8193, Valensi Vol. 4, No. 1, (Mei 2014).

Rahayu, A.N dan Adhitiyawarman., 2014, Pemanfaatan Tongkol Jagung Sebagai Adsorben Besi pada Air Tanah, J. Kimia Khatulistiwa

Sudarmadji, J. Mukono, danCorie I. P. 2006. Toksikologi Logam Berat B3 dan DampaknyaTerhadapKesehatan. Jurnal Kesehatan Lingkungan2(2): 129-142.

Witono, J. A., 2005, Produksi Furfural dan Turunannya: Alternatif Peningkatan Nilai Tambah AmpasTebu Indonesia, (http://www.chem-is-try.org/, diakses tanggal 21 Desember 2017).

Yanuar et al. 2003. Reprinted from Science and Technology Policy for Tablet Excipient (Preparasi dan Karakterisasi Selulosa Mikrokristal dari nata de coco untuk Bahan Pembantu Pembuatan Tablet ) Institute for Science and Technology Studies ( ISTECS ) for Tablet Excipient (', IV(December)

Zheng liuchun, lu guining, cao wei, peng dan, zhu chaofei, lin fangfang, dang zhi. 2013. Modified Cellulose Of Agricultural Resid Used For Removal Of Heavy Metals And Oil: Technologies and Applications. South China University Of Technology, Guangzhou. 